\title{
DAMAGES FOR BREACH OF IRREVOCABLE COMMERCIAL LETTERS OF CREDIT: THE COMMON LAW AND THE UNIFORM COMMERCIAL CODE
}

Unfortunate confusion exists as to the measure of damages for breach of an irrevocable commercial letter of credit. ${ }^{1}$ This is due in part to uncertainty about when the issuing bank's promise becomes a binding obligation, and in part to failure to stress the mercantile functions of the issuing bank's commitment.

The bank's refusal to honor its promise to pay may occur at any of three significant stages during the seller-beneficiary's performance of his sales con-

a party seeking dissolution can go directly to the agency. A party seeking dissolution of a court enforced order of the FTC, which has the power to modify court enforced cease and desist orders, 16 Code Fed. Regs. $\$ 2.27$, 15 U.S.C.A. $\$ 46(\mathrm{~g})$, Rule 27 (Supp., 1956), should go first to the Commission and, if his petition is denied, then appeal to the courts. In Century Metalcraft Co. v. FTC, 112 F.2d 443 (C.A.7th, 1940), the court held that its power to set aside or modify orders of the Commission carried with it the power to modify its own enforcement orders on a showing of changed conditions. However, in American Chain and Cable Co. v. FTC, 142 F.2d 909 (C.A.4th, 1944), the court stated that the condition on which its decree was based was the order of the Commission and that, therefore, this order must be changed before the court could grant dissolution. In Consumer Sales Corp. v. FTC, 198 F.2d 404 (C.A.2d, 1952), the court refused to remand for clarification on the ground that defendant could apply directly to the Commission at any time.

If an agency does not have power to madify its own orders, the party should apply directly to the court. In the absence of statutory authorization an agency does not have the power to modify its orders. See, Suryan v. Alaska Industrial Board, 12 Alaska 571 (D. Alaska, 1950); Olive Proration Committee v. Agricultural Prorate Commission, 17 Cal.2d 204, 109 P.2d 918 (1941); Trigg v. Industrial Commission, 364 Ill. 581, 5 N.E.2d 394 (1936). It appears that even if the party must first go before the court, the court will remand to the agency for findings of fact. In Wallace Corp. v. NLRB, 195 F.2d 952 (C.A.4th, 1947), the court stated that it would grant modification only on the basis of a finding of changed conditions by the Board. But see, Stewart Die Casting Corp. v. NLRB, 129 F.2d 481 (C.A.7th, 1942), in which the court stated that it had the power to modify the cease and desist order and considered the case on its merits. However, in that case the Board had indicated that it had no interest in the result and suggested that the court consider the case on its merits. The procedure of going first before the court and having the proceeding remanded to the Board appears unnecessarily circuitous; but it is clear that, to implement the policy shown by Congress in its grant of fact-finding power to the agency, the agency should have the same power at the time of dissolution as at the time of the action for the enforcement of the decree.

${ }^{1}$ As an example of this confusion, Professor Steffen contrasts the attitude of the court in Stein v. Hambro's Bank, 9 Lloyd's List L. Rep. 507 (1921), where the seller-beneficiary recovered the money equivalent of his draft from the issuing bank, with the attitude in the similar case of Doelger v. Battery Park National Bank, 201 App.Div. 515, 194 N.Y. Supp. 582 (1922), where he recovered only such damages as he would be entitled to against a. buyer for non-acceptance of goods. Steffen, Cases on Commercial and Investment Paper 789 n. 1 (1954).

For further discussion of the proper measure of damages under both the common law and the 1952 version of the Uniform Commercial Code, see Letters of Credit under the Proposed Uniform Commercial Code: An Opportunity Missed, 62 Yale L. J. 227, 254-62 (1953). The draftsmen of the 1957 version of the Code adopted some of the suggestions offered in the Yale note.

See also Finkelstein, Legal Aspects of Commercial Letters of Credit 262-73 (1930). 
tract with the buyer: (1) after the seller has received the letter of credit but before he has substantially performed under the sales contract; (2) after he has substantially performed but before he has presented complying documents and draft to the issuing bank; (3) after he has presented his documents and draft.2 Whether the bank's refusal gives rise to a cause of action in favor of the sellerbeneficiary may depend upon what stage is selected as the one at which the credit becomes binding upon the issuing bank. However, it has never been clearly settled which stage should be selected. ${ }^{3}$ As a result, there has been no agreement on damages.

That the letter of credit should become enforceable immediately upon receipt can be supported by arguing that the word "irrevocable" is intended to have the impact of a seal, ${ }^{4}$ so as to make unnecessary either consideration or substantial performance. ${ }^{5}$ Since the time at which the promise matures into an enforceable obligation would then in no way depend on the conduct of the sellerbeneficiary after he receives the letter of credit, the result arguably could be that damages would be similarly unaffected. The seller would be able to recover "the exact amount named in the letter of credit...." Such an action would be strikingly similar to a suit on a virtual acceptance ${ }^{7}$ with its attendant

${ }^{2}$ As all conditions are then fully performed and no questions of anticipatory repudiation are raised, this stage will not be considered in detail. See note 22 infra.

T The authorities are collected and discussed in Davis, The Relationship between Banker and Seller under a Confirmed Credit, 52 L. Q. Rev. 225 (1936). (The English practice is to call a credit "confirmed" whenever it is irrevocable by its terms.) McCurdy suggests that if the letter of credit is an offer, it is an offer for a unilateral contract and is accepted by presenting draft and documents. Commercial Letters of Credit, 35 Harv. L. Rev. 539, 569 (1922). Mead allows that the offer may be accepted by some act in reliance, such as procuring and shipping goods. Mead, Documentary Letters of Credit, 22 Col. L. Rev. 297, 301 (1922). Gutteridge advances the thought that a bilateral contract may be formed by the banker's promise to pay and the seller-beneficiary's promise to place him in possession of documents of title. Gutteridge, Law of Bankers' Commercial Credits 24 (1932).

4 For the traditional function of the seal see 1 Corbin, Contracts $\$ 252$ (1950).

${ }^{5}$ One view since Lord Mansfield has been that the letter of credit is similar to a specialty: "In commercial cases amongst merchants the want of consideration is not an objection." Pillans v. Van Mierop, 3 Burr. 1663 (K.B., 1765). "It partakes of the nature of a negotiable instrument." Second National Bank v. Samuel and Sons, 12 F.2d 963, 966 (C.A.2d, 1926). See Turner, Letters of Credit as Negotiable Instruments, 36 Yale I. J. 245 (1926).

'Belgian Grain and Produce Co. v. Cox, 1 Lloyd's List L. Rep. 256, 257 (1919). The court did not purport to base its decision upon a seal analogy, as the seller-beneficiary had already performed fully. Compare Stein v. Hambro's Bank, 9 Lloyd's List L. Rep. 507 (1921), note 1 supra.

7 The doctrine of virtual acceptance was established in America by Coolidge v. Payson, 2 Wheat. (U.S.) 66 (1817). According to this decision, "a letter written within a reasonable time before... the date of a bill of exchange, describing it in terms not to be mistaken, and promising to accept it, is, if shown to the person who afterwards takes the bill on the credit of the letter, a virtual acceptance binding the person who makes the promise." Id., at 75.

The doctrine in a modified form appears in NII \$135: " $\mathrm{An}$ unconditional promise in writing to accept a bill before it is drawn is deemed an actual acceptance in favor of every person who, upon the faith thereof, receives the bill for value." It appears that the requirement of 
simplicity ${ }^{8}$ of pleading and proof.

In one aspect, this measure of damages would seem consonant with the mercantile function of the letter of credit. The seller-beneficiary would be certain of payment by the issuing bank, without the risks of a contumacious or dilatory buyer.' Other banks which are willing to carry the burden of financing ${ }^{10}$ the seller-beneficiary would likewise be assured of payment should the terms of the credit then be complied with. Being virtually in the position of holders of an accepted draft, ${ }^{11}$ the banks would be able to allow a lower discount rate.

But the promise in a letter of credit is, in a very real sense, conditional ${ }^{12}$

showing the letter has been dropped and that a new requirement that the promise be unconditional has been added to the old doctrine.

Virtual and extrinsic acceptances of inland bills were abolished in England in 1821, 1 \& 2 Geo. IV, c. 78, $\$ 2$ (1821), and of all bills in $1856,19 \& 20$ Vict., c. $97, \$ 6$ (1856). Nevertheless, Ex parte Asiatic Banking Corp., [1867] L.R. 2 Ch. App. 391, seems to have treated the issuing bank as an acceptor, setting a precedent followed in Belgian Grain and Produce Co. v. Cox, and, Stein v. Hambro's Bank, note 6 supra. See Finkelstein, Legal Aspects of Commercial Letters of Credit 50, 92 (1930).

The 1957 version of the Uniform Commercial Code requires that the acceptance be written on the draft itself. Uniform Commercial Code $\$ 3-410$.

${ }^{8}$ See the presumptions stated in NUL Sections 14 (blanks), 16 (delivery), 24 (consideration), and 59 (holder in due course). "It is elementary in the law of bills of exchange that the payee (seller) may recover of the acceptor (bank) provided only that he took in good faith, before maturity and for value." Turner, Letters of Credit--Negotiable Instruments, 36 Yale L. J. 245, 251 (1926).

2 "The cardinal feature of the transaction is that the seller is not content to rely on the buyer's ability or readiness to pay the price, but insists on payment being made in such a form as will obviate the possibility, not merely of any danger of the buyer's insolvency, but also of any resort to chicanery for the purpose of delaying or defeating payment." Gutteridge and Megrah, The Law of Bankers' Commercial Credits 20 (1955). Of great importance is that the seller-beneficiary no longer risks litigation over breach of warranty before he has been paid. Instead he risks litigation over conformity of documents with the issuing bank, which is normally unwilling to endanger its international reputation on frivolous grounds.

10 Typical financing occurs by way of discount of the draft after manufacture has been completed and the required documents procured. However, immediate financing upon receipt of the credit may take the form of a "back-to-back" letter of credit, by which the sellerbeneficiary uses the original credit to support an ancillary credit granted by his own banker to his supplier. Or the seller-beneficiary may obtain an outright loan on the strength of the letter before beginning manufacture, usually by assigning proceeds of the letter. See Harfield, Secondary Uses of Commercial Credits, 44 Col. L. Rev. 899 (1944). If the letter is an enforceable obligation against the issuer immediately upon receipt, the seller's banker has security no matter when the issuer subsequently repudiates.

11 This of course is what is meant by a virtual acceptance. See note 7 supra. When the financing bank has actually discounted the draft and the accompanying documents comply with the conditions of the credit, there is no doubt that the bank as a bona fide purchaser may view the draft as accepted. Prehn v. Royal Bank of Liverpool, [1870] L.R. 5 Ex. 92; Russell v. Wiggin, 21 Fed. Cas. No. 12,165 (C.C. Mass., 1842).

12 If the seller-beneficiary does not comply with the conditions the bank has a right to refuse payment. The conditions would appear to take the documentary commercial credit out of NIL $\$ 135$ on virtual acceptance. See note 7 supra. Only in the case of the unconditional 
and the conditions are closely related to the sales transaction. Consequently courts, with few exceptions, ${ }^{13}$ have not adopted a virtual acceptance theory. Perhaps partly because of its conditional nature, ${ }^{14}$ and partly because of theoretical difficulties ${ }^{15}$ with consideration, courts have not allowed the bank's obligation to ripen until the seller-beneficiary has taken certain steps in reliance under the sales contract. ${ }^{16}$ This may mean either substantial performance creating promissory estoppel ${ }^{17}$ or complete performance amounting to acceptance of an offer for a unilateral contract. ${ }^{18}$ Since liability, then, cannot be determined without reference to factors also present in the sales contract, the courts have apparently thought that damages similarly must be determined by sales law. ${ }^{19}$ The consequence is that damages must vary according to such

"clean" credit would the theory of virtual acceptance be available. Under a "clean" credit, the beneficiary need present no documents with the draft. Such a credit is generally used to cover bona fide shipments of goods, but it is also a device for speculations in exchange for financing a prospective shipper who in reality is the buyer's agent for procurement. Ward and Harfield, Bank Credits and Acceptances 9 (3rd ed., 1948).

18 E.g., Stein v. Hambro's Bank, 9 Lloyd's List L. Rep. 507 (1921); Belgian Grain and Produce Co. v. Cox \& Co., 1 Lloyd's List L. Rep. 256 (1919).

1s There exists concern that the seller-beneficiary may receive a windfall unless he can show ability to perform the sales contract. See Doelger v. Battery Park National Bank, 201 App.Div. 515, 194 N.Y.Supp. 582 (1922).

${ }^{15}$ The virtual acceptance or specialty theories are not favored by the authorities, each of whom has his own solution to the problem. See Gutteridge and Megrah, The Law of Bankers' Commercial Credits 14 (1955); Finkelstein, Legal Aspects of Commercial Letters of Credit 279 (1930); McCurdy, Commercial Letters of Credit, 35 Harv. L. Rev. 539, 564 (1922); Thayer, Irrevocable Credits in International Commerce: Their Legal Nature, 36 Col. L. Rev. 1031 (1936); Trimble, The Law Merchant and the Letter of Credit, 61 Harv. L. Rev. 981 (1948). For a compact summary and criticism of many of these theories consult Ilewellyn, Cases and Materials on the Law of Sales 829 (1930).

${ }^{16}$ American Steel Co. v. Irving National Bank, 266 Fed. 41, 43 (C.A.2d, 1920); Urquhart Lindsay v. Eastern Bank, [1922] 1 K.B. 318, 321.

I7 Johannessen v. Munroe, 158 N.Y. 641, 53 N.E. 535 (1899). See Rest., Contracts $\$ \$ 45$, 90 (1932).

18 " [A] letter of credit is an offer by a bank or other financial agency to be bound to the person to whom it is directed, when accepled and acted upon by the latter according to its stipuliations." Moss v. Old Colony Trust Co., 246 Mass. 139, 151, 140 N.E. 803, 808 (1923) (emphasis supplied). This dictum has not been followed because it smacks too much of $A$ revoking when $B$ is almost to the top of the flagpole; it would permit the issuing bank to revoke at any time before presentation of draft and documents, thus eliminating the feasability of seller financing.

19 See Uniform Sales Act $\$ \$ 1,52,63,64,70$; English Sale of Goods Act $\$ \$ 1,38,49,50$, 54. Any literal application of these acts would not be possible, as the seller nowhere agrees to transfer "property in the goods" to the issuing bank; there is no contract to sell to the bank. Any analogy to the provisions of these acts is also faulty. The assumption is that the buyer has no counterclaim against the seller-beneficiary, since only then could the measure of damages properly be the same against both buyer and bank. Yet cases of wrongful cancellation of a credit usually arise because the buyer does have a counterclaim, or at least asserts that he has one.

Assuming that the sales measure of damages would allow recovery of the price of the 
factors as whether title has passed, ${ }^{20}$ whether there is a determinable market price at the time and place for tender, ${ }^{21}$ and whether repudiation of one installment is repudiation of the whole contract.22

As to measure of damages, existing sales law is not entirely satisfactory, even when applied only to sales contracts. ${ }^{23}$ Moreover, pleading and proof

goods in some instances, and that the credit is for less than the price, then an absurd result is reached. The bank would be forced to pay the seller not only the credit amount but also an additional amount for which the seller-beneficiary has agreed to look only to the buyer. See Professor Llewellyn's Introduction to Finkelstein, Legal Aspects of Commercial Letters of Credit xxii (1930).

${ }^{20}$ Uniform Sales Act $\$ 63$. This section compromised between the rule of the English Sale of Goods Act, which permits an action for the price only where title to the goods has passed to the buyer, and the liberal "New York rule" which allowed an action for the price at the option of the seller whenever there was a contract. 2 Williston, Sales $\$ 562-66$ (2d ed., 1924). Thus where goods could not be readily resold for a reasonable price, even though title had not passed, action for the price would lie. But the ambiguities of "readily be resold" and "reasonable price" proved too much for the courts, and the mystic element of "title" usually was a prerequisite to an action for the price. Llewellyn, Through Title to Contract and a Bit Beyond, 15 N.Y.U. L. Q. Rev. 159, 175-82 (1938).

21 Uniform Sales Act $\$ 64$. This problem arises when the goods are not generally marketable and is especially complicated when repudiation is anticipatory, as an examination of the following letter of credit cases reveals.

In Urquhart Lindsay Co. v. Eastern Bank, [1922] 1 K.B. 318, two installments of specially manufactured machinery had been shipped and duly paid for by the bank, but upon shipment of a third installment the bank refused to take up documents and to accept the draft. The seller-beneficiary sued for breach of the entire remaining portion of the credit. Damages awarded were the "difference between on the one hand the value of the materials left on their hands and the cost of such as they would have further provided, and, on the other hand, what they would have been entitled to receive for the manufactured machinery, the whole being limited to the amount they could in fact have tendered before the expiry of the letter of credit." The measure is one of anticipated profits, Uniform Sales Act $\$ 64(4)$.

This measure of anticipated profits was applied by the Appellate Division in Foglino and Co. v. Webster, 217 App.Div. 282, 216 N.Y.Supp. 225 (1926). The Court of Appeals, however, reversed and replaced the profit measure by the non-acceptance of goods measure, Uniform Sales Act $\$ 64(3)$ - the difference between contract and market price at the time and place for tender. The contract was not for specially manufactured goods but for coal which had not yet been loaded for shipment when the seller-beneficiary learned of the bank's repudiation. The Court of Appeals held that the seller-beneficiary's contract with his supplier to purchase coal at more than the market price at time of tender was immaterial and that although it would have reduced the seller's profit had the defendant performed, it did not reduce his loss by having the coal left on his hands to dispose of in a falling market. 244 N.Y. 516, 155 N.E. 878 (1926).

$\approx$ Under sales law there would be an action on the single instalment only, unless the breach went to the essence of the sales contract. 4 Corbin, Contracts $\$ \$ 972-73$ (1950). The application of this doctrine to drafts drawn under a letter of credit presents a difficult problem. Compare Doelger v. Battery Park National Bank, 201 App.Div. 515, 194 N.Y.Supp. 582 (1922) (first of series of drafts dishonored five days before credit expired; court expressly declined to award damages on basis of anticipatory breach) with Urquhart Lindsay Co. v. Eastern Bank, [1922] 1 K.B. 318, note 21 supra.

${ }^{23}$ E.g., 1 a Uniform Laws Annotated $\$ 64$, Action for Damages for Non-Acceptance of Goods. Under this Uniform Sales Act provision the seller, whose damages are firmly riveted to the time of delivery, may suffer a loss for which there is no compensation if the market continues to fall while he searches for a new buyer. 
are more complex than they are in an action for the face amount of the credit..24 Even so, it may be argued that there are two reasons why the sales measure of damages is preferable to that which allows an action in all cases for the exact amount promised in the credit.

For example, it would be preposterous to contend that the bank should be penalized in the case of anticipatory repudiation by having to pay the face amount of the credit without any allowance for the expenses the seller saves because of an early cancellation. The sales measure takes into account the seller-beneficiary's duty to minimize damages. ${ }^{25}$ Secondly, the sales measure also takes into account the seller-beneficiary's right to incidental damages, ${ }^{26}$ since it would be inequitable not to allow him to recover from the bank his outlays for. custom fees, brokerage, hauling and warehousing for the goods already completed.

In contrast, the theory based on the virtual acceptance analogy, by implying that the sales contract is unrelated to the letter of credit, ${ }^{27}$ would appear to impose no duty to minimize damages and also to allow no right to incidental damages. ${ }^{28}$ But no measure of damages based strictly upon a single theory of the time at which the credit becomes enforceable can accommodate within itself all three features deemed essential: certainty of payment, minimal damages, and the granting of incidental damages to the seller. The impasse thus reached, however, has been resolved by the 1957 Uniform Commercial Code, ${ }^{29}$ which measures damages without rigid adherence to any prior theory. Instead it provides elastic measures designed to make the aggrieved party whole.

As respects consideration ${ }^{30}$ and the time when the obligation becomes binding, the Code adopts a specialty theory. ${ }^{31}$ "Unless otherwise agreed a

24 See notes 21, 22 and 23 supra.

${ }^{35}$ O'Meara v. National Park Bank, 239 N.Y. 368, 400, 146 N.E. 636, 640 (1925), indicates that the seller-beneficiary has a duty of resale.

${ }^{20}$ In accord with the rule in Hadley v. Baxendale, [1854] $9 \mathrm{Ex} .341$, are the following letter of credit cases: De Sousa v. Crocker First National Bank, 23 F.2d 118, 122 (N.D. Cal., 1927), rev'd on other grounds, 27 F.2d 462 (C.A.9th, 1928) and In re Barned's Banking Co., Coupland's Claim, [1869] I.R. 5 Eq. 167, 169.

${ }^{27}$ There is support for this implication in the loose language of cases where the bank attempts to revoke its credit on grounds that the seller-beneficiary has breached the sales contract: "[T]he letter of credit was not part of the contract between the buyer and the seller, but was an entirely separate and independent contract between the bank and the seller," Jones \& Co. v. Bond, 191 Cal. 551, 555, 217 Pac. 725, 727 (1923); "A bank issuing a letter of credit is in no way concerned with any contract existing between the buyer and seller," Imbrie v. Nagase \& Co., 196 App.Div. 380, 383, 187 N.Y.Supp. 692, 695 (1921).

${ }^{28}$ In Stein v. Hambro's Bank, 9 Iloyd's List I .Rep. 507 (1921), the matter was considered but the court did not decide whether if the bank wanted the documents it would have to pay the seller-beneficiary the warehouse charges.

${ }^{29}$ See generally Uniform Commercial Code, Art. 5 (Letters of Credit), and specifically $\$ \$ 5-106,5-114(1)$ and 5-115.

${ }^{30}$ "No consideration is necessary to establish a credit. ..." Id., at $\$ 5-105$.

s See note 5 supra. 
credit is established as regards the beneficiary when he receives a letter of credit...."32 and "once an irrevocable credit is established... it can be modified or revoked only with his consent." 33 Consistent with this theory, it permits an action for the exact amount of the credit. But this immediate ${ }^{34}$ right is limited to cases where the seller-beneficiary has not learned of cancellation "in time reasonably to avoid procurement of the required documents." Where he has learned "in time," the flexible measures of damage found in the Sales Article apply. ${ }^{36}$ These measures allow the eventual recovery of the exact credit amount only in the atypical case where the goods are already "identified to the contract" to resell them at a reasonable price or the circumstances reasonably indicate that such effort will be unavailing." ${ }^{\text {38 }}$

The sum of these rules, however, does not mean that the Code implicitly adopts a reliance theory, since anticipatory repudiation is actionable as soon as the letter of credit has been received. Nevertheless the Code does not ignore the sales aspect of the transaction, as it requires the seller-beneficiary to minimize his loss up to the time that the required documents have been procured. ${ }^{39}$ After that time, he is given an option of resale. ${ }^{40}$ In any event, incidental damages are awarded. ${ }^{41}$

The reason the Code employs any sales measure at all is to ensure that economic loss is minimized. Certainty about the amount of payment is sacrificed, but this sacrifice is unimportant as a draft purchaser will never sue for anticipatory repudiation. What little hardship the seller may suffer is reduced by provisions which remove much of the difficulty in determining a market price for damage purposes. ${ }^{42}$ It may then be argued that the pressures which the Code puts on a seller to resell goods still in his control and within his

32 Uniform Commercial Code \$5-106(1).

${ }^{33}$ Id., at $\$ 5-106(2)$.

34 "Immediate" in the sense that the seller-beneficiary need take no steps to resell goods as a condition for recovery.

${ }^{35}$ Id., at $\$ 5-115(2)$. The crucial document will generally be the bill of lading.

${ }^{36} \mathrm{Id}$., at $\$ 2-703$, lists the alternative remedies referred to in $\$ 2-610$, to which there is reference in $\$ 5-115(2)$. Where "contract price" or "price of goods" appears as a measure in these remedies it would appear necessary to substitute "credit amount," for the reasons discussed in note 19 supra.

$$
{ }^{37} \text { Id., at } \$ \$ 2-709 \text { (1) (b), 2-501(1). } \quad{ }^{38} \text { Id., at \$2-709(1). }
$$

${ }^{39}$ Id., at $\$ 5-115(2)$. Note that wrongful dishonor of one draft for a portion of the credit is automatically equivalent to anticipatory repudiation of the rest of the credit, $\$ 5-112$, thus resolving one of the difficulties of prior case law. See note 22 supra.

10 Id., at $\$ 5-115(1)$. The commercial good sense of this provision is evident. Where goods are in transit or are in a strange territory, making their disposal difficult, the seller-beneficiary can recover the full amount of the draft. However the resale provision may at other times prove more valuable, as the seller will usualiy wish to realize cash at the earliest possible date, without waiting for the termination of uncertain and perhaps protracted litigation against the bank. The proceeds of resale are then deducted from the draft amount in the final judgment.

$$
\text { 4Id., at \$\$5-115(1), 2-710. } \quad \text { Id., at \$2-723. }
$$


own territory are consistent with sound commercial policy. ${ }^{43}$ Thus it would appear that enactment of the Code would dispel much of the confusion about the measure of damages for breach of an "irrevocable" commercial letter of credit.

${ }^{48}$ It has been urged, however, that it would be better policy to advance the point when a credit becomes incontestable, and thus to avoid, so far as possible, postponing the beneficiaryseller to the vagaries and delay of a damage action. Steffen, Irrevocable Credits and the Law, - J. Business Law - (London, 1958).

\section{A CRITICAL ANALYSIS OF RULES AGAINST SOLICITATION BY LAWYERS}

Although several of the ancient rules regulating the professional conduct of lawyers have been discarded in America, ${ }^{1}$ those prohibiting the solicitation ${ }^{2}$ of professional employment have gone almost unchallenged. ${ }^{3}$ Writers on the subject of solicitation have tended to limit their treatment to a description of the rules and have not undertaken a critical examination of the reasons given for those rules. The approach taken by the writers may in some measure be justifiable. A critical analysis of the rules must of necessity be inadequate, for the rules are based in part on deeply ingrained feelings of tradition, ${ }^{5}$ honor and service. Lawyers have for centuries emphasized that the promotion of justice, rather than the earning of fees, is the goal of the profession. Moreover, it is felt that solicitation, with its emphasis on economic ends, may hamper the establishment of the proper attorney-client relationship. These considerations, seldom articulated, will have to be weighed in the final evaluation of the rules against solicita-

1 The outstanding example is the elimination of the rule against contingent fees. See generally Radin, Maintenance by Champerty, 24 Cal. L. Rev. 48 (1935).

2 The Canons of Professional Ethics make a distinction between advertising and direct solicitation. Canons 27 and 28, A.B.A., Canons of Professional Ethics (1957). The comment will be devoted primarily to the latter and will assume that any doubts concerning the present rules against direct solicitation would apply with equal or greater force to the rules against advertising. Compare the dissent in In re Schwarz, 231 N.Y. 642, 132 N.E. 921 (1921) (advertising) with People v. Culkin, 248 N.Y. 465, 162 N.E. 487 (1928) (direct solicitation).

'At least two significant challenges have occurred. With his article, The Bugaboo, "Ambulance Chasing," 6 Cal. S. B.J. 37 (1931), James F. Brennan provoked a flurry of controversy in the pages of the California State Bar Journal. Recently Mr. Justice Bristow of the Illinois Supreme Court said that he was unable to reconcile the rules against solicitation with the condoned practice of gaining clients at country clubs. In re Cohn, $10 \mathrm{ml} .2 \mathrm{~d} 186,196,139$ N.E.2d 301,306 (1956) (concurring opinion).

4 See, e.g., Drinker, Legal Ethics 64 (1953); Ambulance Chasing, 30 N.Y.U. L. Rev. 182 (1955); Advertising, Solicitation, and Legal Ethics, 7 Vand. L. Rev, 677 (1954); Settlement of Personal Injury Cases in the Chicago Area, 47 Nw. U. L. Rev. 895 (1953).

${ }^{5}$ It should, however, be emphasized that the ability of the legal profession to adjust to changes in rules governing its conduct ought not to be underestimated. In its long history the profession has adjusted to several such changes. See Lawyer's Tightrope-Use and Abuse of Fees, 41 Cornell L. Q. 683, 684-89 (1956), for a discussion of the profession's adjustment first to the fee and later to the contingent fee. 